\title{
Improving geoinformation technology by incorporating local participation
}

Sandy Budi Wibowo, Idea Wening Nurani

Sandy Budi Wibowo, Idea Wening Nurani, "Improving geoinformation technology by incorporating local participation," Proc. SPIE 11311, Sixth Geoinformation Science Symposium, 113110C (21 November 2019); doi: $10.1117 / 12.2550320$

Event: Sixth Geoinformation Science Symposium, 2019, Yogyakarta, Indonesia 


\title{
Improving geoinformation technology by incorporating local participation
}

\author{
Sandy Budi Wibowo ${ }^{* a}$, Idea Wening Nurani ${ }^{\mathrm{b}}$ \\ aDepartment of Geographic Information Science, Faculty of Geography, Universitas Gadjah Mada, \\ Second Floor, Building D, Bulaksumur, Sleman, Yogyakarta Special Region, Indonesia 55281; \\ ${ }^{b}$ Department of Development Geography, Faculty of Geography, Universitas Gadjah Mada, Second \\ Floor, Building D, Bulaksumur, Sleman, Yogyakarta Special Region, Indonesia 55281
}

\begin{abstract}
The development of Jimbung Village, Klaten Regency, Central Java Province requires good spatial database to maximize its resources. However, GIS specialists who master GeoInformation Technology still need specific local knowledge so that the participation of local communities is extremely valuable. The objective of this research is to improve GIS products by incorporating local participation. We conducted aerial and surface observation within the village area in order to complete GIS database on village boundary delimitation, current potencies (industry, food and beverage, agriculture, tourism). Participatory Learning and Action was used to identify the future development of village. The results show that Participatory Geoinformation Technology allows to clearly identify the industrial development, small medium enterprises on processed food, agricultural activity, and tourism in Jimbung village. Active participation from stakeholders can also help identify potential sectors that need to be developed in the future. This would be very important for local government while composing Middle Term Village Development Plan (RPJMDes).
\end{abstract}

Keywords: Geoinformation, technology, local participation

\section{INTRODUCTION}

Geoinformation technology is widely used for technical analysis of rural development and planning [1,2,3,4]. This often requires good spatial database to fulfil the potential of rural area [5]. However, each village has distinct characteristic and some remote rural area does not have proper spatial data [6]. Without possessing deep knowledge of the area, GIS technical analysis in laboratory needs to be carefully validated. Incorporating local participation in geoinformation technology is very important because it would be one possible solution in order to ameliorate the end products of GIS analysis.

Jimbung Village, Klaten Regency, Indonesia is currently trying to improve its non-agricultural sector by using GIS approach. Nowadays, rural agriculture sector is already well organized by its 9,919 residents thanks to average rainfall of $1459.2 \mathrm{~mm} /$ year. The climate of Jimbung Village consists of 5 dry months, 1 humid month and 6 wet months. Agriculture is carried out on Entisols (USDA soil classification) or Regosols (FAO soil classification), which are formed from weathered volcanic parent materials. Eight local farmer groups are quite effective in managing rice as the main commodity, as well as additional commodities such as corn, peanuts, sugar cane. This farmer groups also manages 198 cows, 27 buffaloes, 6 horses, 465 goats, and 24,573 poultry [7]. In consequence of a famous folklore of the mystifying origin of turtles Bulus Jimbung living in local lake $(151 \mathrm{~m}$ asl), Jimbung Village is able to attract many curious visitors. This would turn tourism sector into a new potential flagship sector and should be integrated with rural agricultural sector. Not to mention, its geographical location adjacent to the Rowo Jombor Reservoir makes the rural agricultural sector have a great potential to be integrated with the tourism sector. Spatial development of tourism sector is actually quite challenging because only $40.4 \%$ of the village area is dedicated for non-paddy field land use (161.2 ha of the total area of the village of $399.8 \mathrm{ha}$ ). However, village inventory land is still 43.9 ha. The land can certainly be empowered if the village government is interested and serious the tourism sector.

\footnotetext{
*sandy_budi_wibowo@ugm.ac.id; phone+622746492331; fax +62274589595; http://saig.geo.ugm.ac.id
} 
The main problem that arises is the need for characterization of rural areas to optimize non-paddy field land use for tourism purposes due to the limited application of mapping technology in the community $[8,9]$. The characterization of participatory areas has to be emphasized because it will incorporate detailed local knowledge is only owned by local residents [10].

This study aims to: (1) identify the spatial resources of Jimbung Village to support the diversification of the leading sectors, and (2) to combine the latest geo-information technology and local community knowledge in the form of participatory mapping.

\section{METHODS}

This study is focused on Jimbung village, Klaten Regency, Indonesia. The first constraint is that there is no clear village boundary provided by governmental institutions. In consequence, village boundary has to be determined. It is carried out in 3 steps: (1) Acquisition of village boundary shapefile collection from InaGeoportal and making tentative village boundary map layouts, (2) direct correction of village boundaries on the tentative boundary map by village officers, and (3) survey and boundary tracking in the village together with the village officers in the field allowing us to record the coordinates of the boundary marks. The $14.27 \mathrm{~km}$ Jimbung Village Boundary Map is later demoted to the Community Boundary Map (RW).

The identification of biotic, abiotic and social conditions is carried out by relying on aerial and surface observation (Figure 1). The effectiveness and flexibility of aerial observation using satellite imagery and Unmanned Aerial Vehicles (UAVs) are used as the key of a quick survey in the area that covers the entire village. UAV's flight path is predetermined using flight planner to take aerial photographs upright from a height of $100 \mathrm{~m}$ with an area of overlapping area between photos by $60 \%$. The aerial photo is combined into an aerial photo mosaic and then displayed on an administrative map. Surface observations are carried out to validate the results of identification through aerial observation. Stratified random sampling on map units is applied to get good accuracy without spending a lot of time for sampling. The results of assessing abiotic, biotic and social conditions are combined in the Geographic Information System (GIS) database.

The village development plan is obtained from Focus Group Discussions (FGDs), which are attended by village stakeholders (Government, developers, entrepreneurs, and local community). The FGDs are held twice in 2018 and are attended by 10 and 25 people for the first and second FGD consecutively. The FGDs focus on gathering information about village development programs that have been, are being and will be implemented for at least the next 3 years.

The GIS database that has been produced in Work Package 1 (WP 1) is combined with the knowledge of local communities about their area (WP 3). Acquisition of spatial information is packaged in the form of PLA (Participatory Learning and Action) on the description $(5 \mathrm{~W} 1 \mathrm{H})$ of each attribute on each entity on the map. All abiotic, biotic and social information and also village development plans are outlined in the form of village maps (WP 4) to facilitate community understanding of village spatial aspects.

\section{Objective 1. Identification of spatial resource}

Objective 2. Participatory Mapping

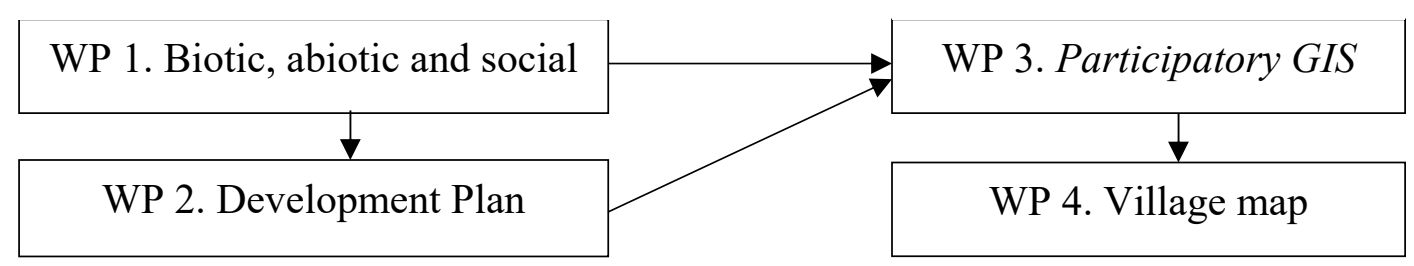

Figure 1. Methods are broken down into four Work Packages (WP). 


\section{RESULTS AND DISCUSSION}

\subsection{Administration Map}

Jimbung Village with a total area of 4,537,750 $\mathrm{m}^{2}$ (453 ha) consists of 29 smaller administrative/hamlet areas called Rukun Warga/RW (Figure 2). Determination of RW boundaries is based on interviews with RW leaders and local residents during boundary tracking using the Global Positioning System (GPS). After determining the administrative boundaries at the village and RW levels, UAV was used to map land use in the Jimbung village area in detail. We found that several version of administrative boundaries maps have been produced without the same geometry. Village officer was really helpful to produce the right administrative boundaries. It is fundamental for further analysis in GIS [11,12].

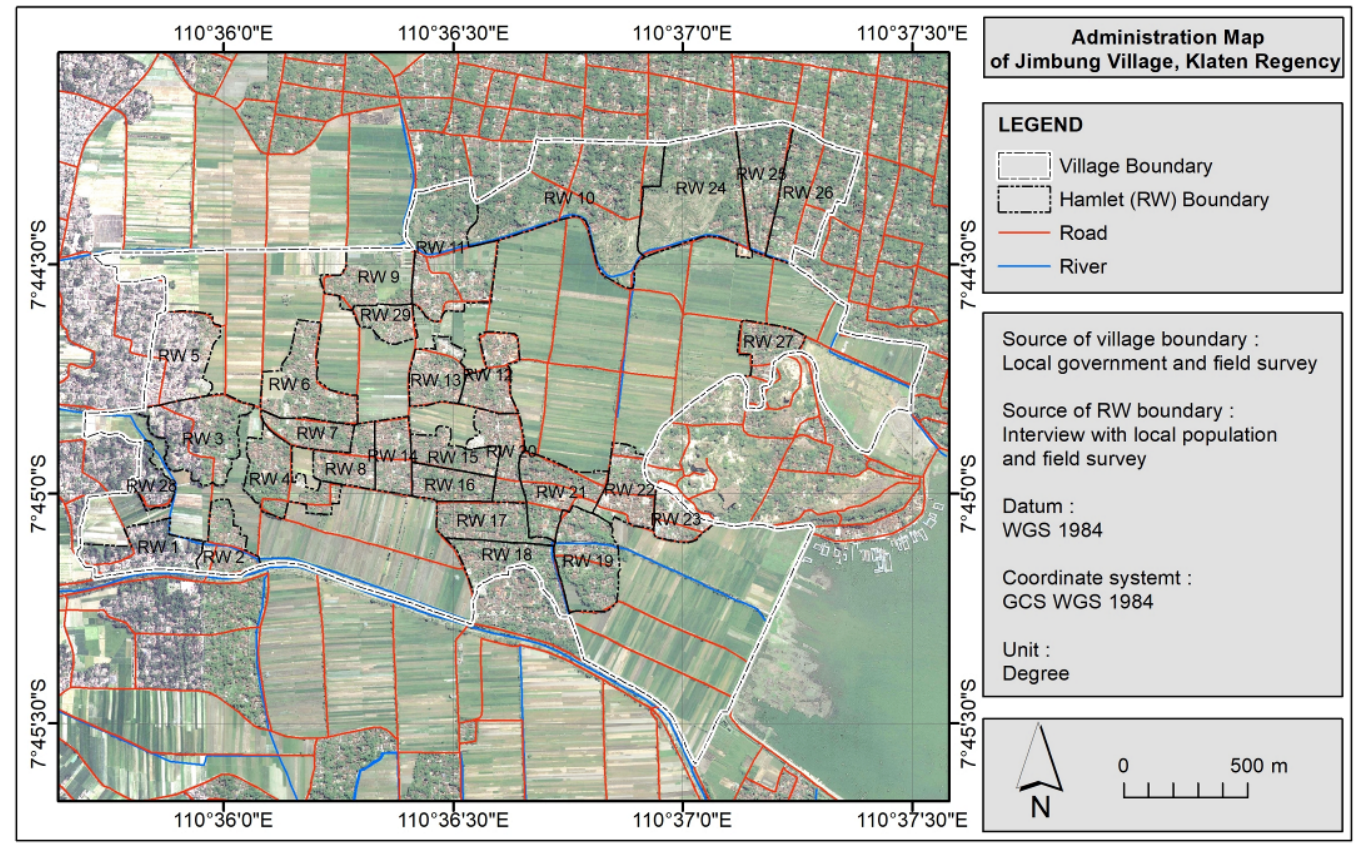

Figure 2. Detailed administrative map of the study area.

\subsection{Resources Maps}

Based on field observations including geomorphological, land use and socio-economic assessments, we intended to make village's potential activities map that includes: Industry, Processed Foods, Agriculture and Animal Husbandry, and Tourism. Industries in Jimbung Village are generally classified as household scale with various leading commodities such as brick, furniture, light cup, tile, brick, pottery, laundry deodorizer, placard, gravestone, and nameplate (Figure 3). In addition to industry, Jimbung Village also has various types of SMEs (Small and Medium Enterprises) that are involved in processed foods. Like other rural areas, Jimbung Village is inseparable from agricultural activities. Paddy fields of 238.5 ha (more than $50 \%$ of the village area) indicate that rice cultivation are still dominant. Spatial distribution of paddy fields is found in the northwest, east, southeast and south of Jimbung Village. This is in accordance with the geomorphology of Jimbung village in the form of alluvial plains so that it is suitable for rice cultivation. In addition to rice cultivation, Jimbung Village also promotes horticultural crops such as cucumbers, onions, melons and chilies in the western end of the Jimbung Village Area (Figure 3).

Animal Husbandry in Jimbung Village is another potential sector that can be developed much more optimally. Jimbung village is famous for its starling bird farms which are spread in the central part (RW 7, RW 13, RW 14, RW 16), east (RW 23), and north (RW 11) village area. Training facilities and bird competitions are also available. However, starling Farms are highly dependent on the latest government policy updates that classify and exclude starlings from the list of protected animals. Besides starlings, Lovebird birds are also a commodity developed in the central (RW 14) and northern (RW 9 and RW 29) villages of Jimbung. Besides birds, fish farming is also being promoted, especially Gourami and Nila fish in RW 12 and RW 9. 


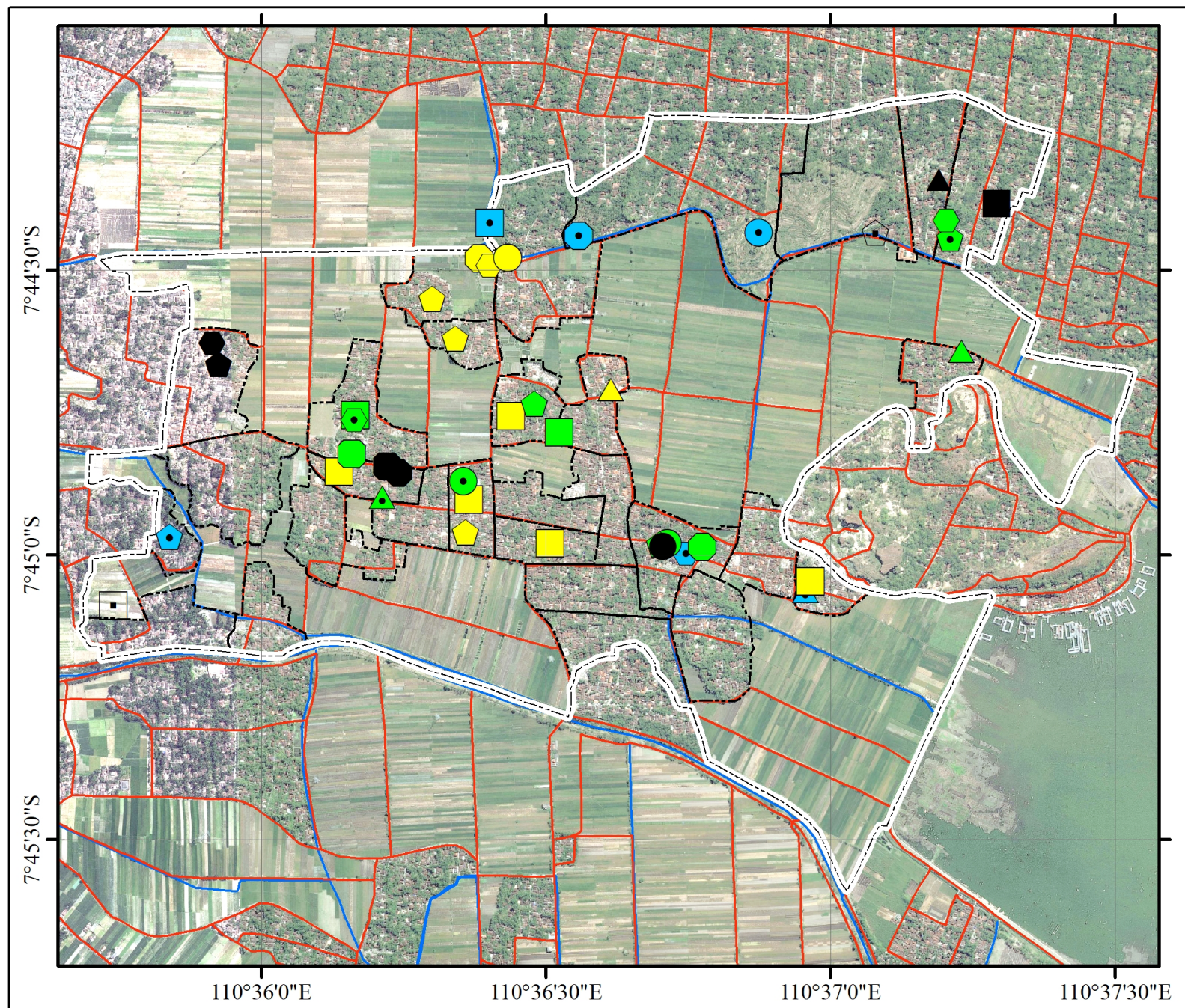

\section{LEGEND}

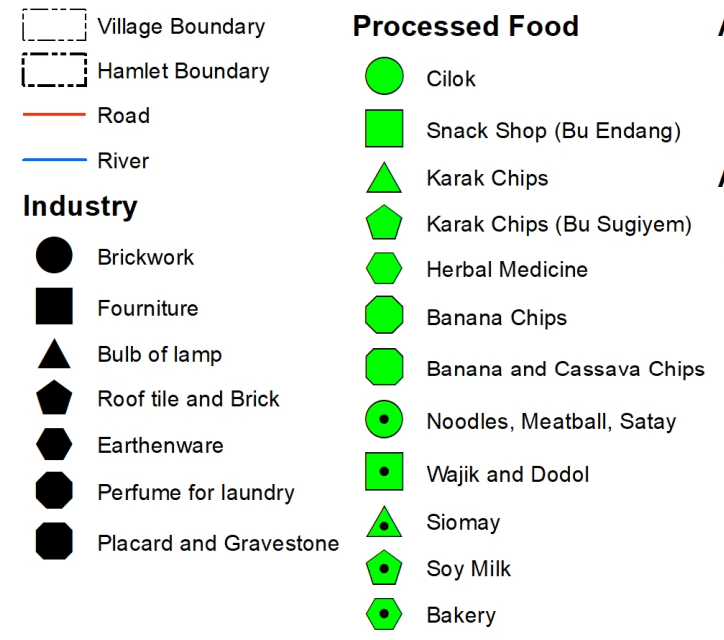

\section{Agriculture}

- Lestari Farmer Group

- Plantation of Cucumber, Melon, Chili

\section{Animal Husbandry}

ANF Bird Farm

Bali Myna (Leucopsar rothschildi)

Fish Pond

Lovebird (Agapornis personatus)

Gourami (Osphronemus goramy)

Bird Training Center and Contest

\section{Tourist Attractions}

- Bukit Pertapaan

- Jimbung Tebing Gebyok

- Tirta Pelangi Pool

- Cemetery of Panembahan Rama

- Cemetery of Pangeran Palgunadi

- Bulus Lake

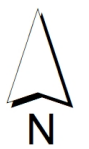

Figure 3. Potential sectors of Jimbung village. 
The potentiality of Tourism sector cannot be ruled out. Sendang Bulus is a very prominent tourist attraction from Jimbung Village which is located in the southeastern part of the Village area (RW 21). In addition, there are religious tourism such as the Tomb of Panembahan Rama (RW 28), the Tomb of Pangeran Palgunadi and Bukit Pertapaan (RW 10). Jimbung Village also developed the Jimbung Tebing Gombyok / JTG Tourism area to the north of the village.

\subsection{Future development of Jimbung Village}

Active participation from local stakeholders is fundamental for spatial identification of the development plan of Jimbung Village. A very striking development is the conversion of agricultural land into settlements and shophouses (Rumah Toko). This conversion is done by justification that agricultural land is no longer productive or agricultural land is in the form of swamps that is almost permanently inundated. Spatial distribution of residential locations that want to be developed is in the eastern, central, southern and northeastern parts of Jimbung Village (Figure 4). The construction of settlements is preffered on the side of the main road because of easy accessibility.Some of the agricultural land which currently has a total area of more than $50 \%$ of the Jimbung Village area will also be converted to an industrial estate. The area is located in the northeast of the village, precisely in the south of RW 24. Unveiled spatial planning of this industrial area leads to a polemic over the acquisition of agricultural land in the region. The reason for choosing the location of agricultural land to be converted is the same as the argument for the conversion of agricultural land for settlement, namely the decreasing productivity of agricultural land. The development of Jimbung Village is not only through land conversion, but also the conversion of existing potentials, such as the Fish Seed Hall, Multipurpose Building, Bata Genting Center, Sports Center, Horticultural Center, Kampung Jalak, as well as Riverside.

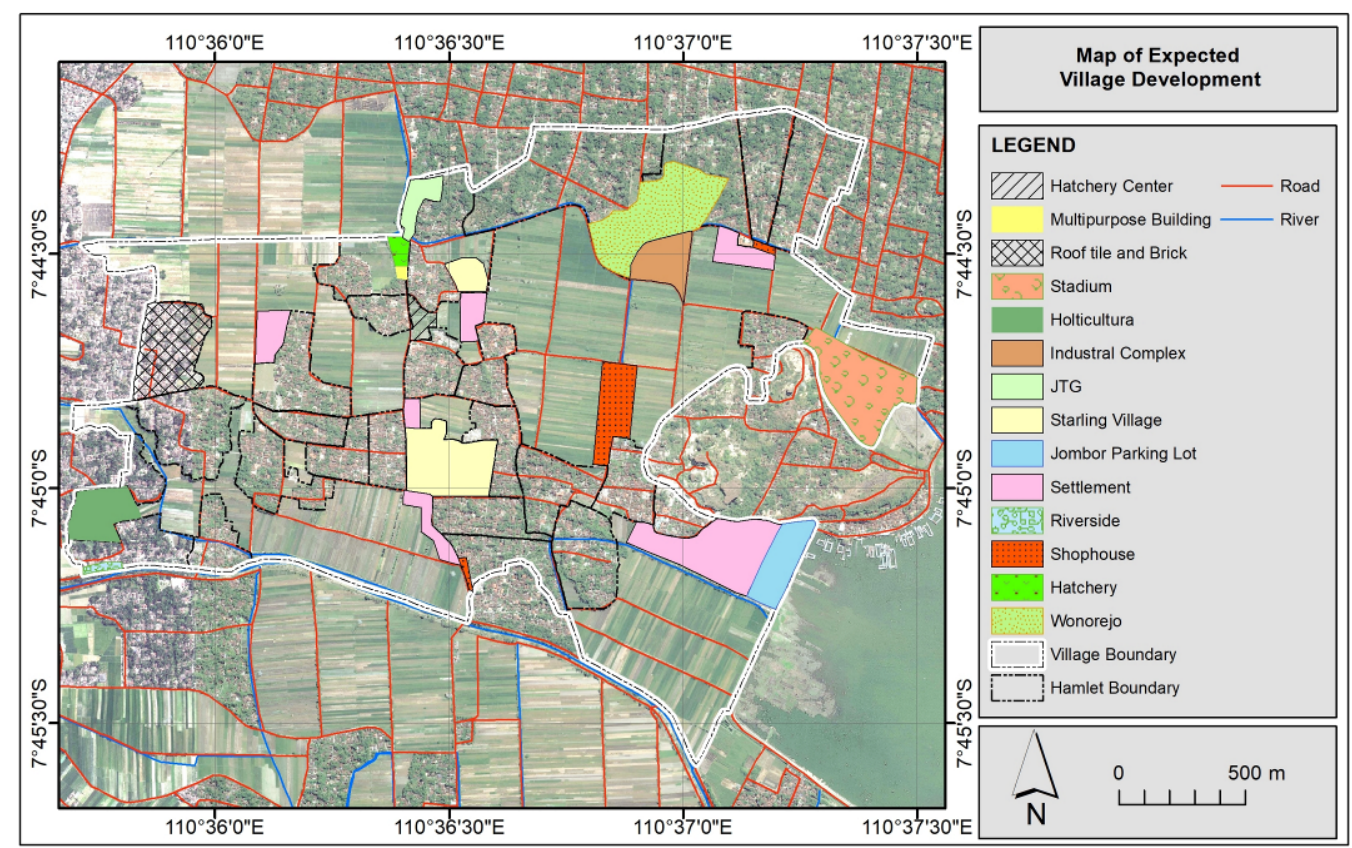

Figure 4. Future development of the village based on local participation.

The forestry sector will also be integrated with the tourism sector by building two attractions, namely Jimbung Tebing Gobyok (JTG) and Wonorejo. The idea of the construction of the location of the attraction comes from the desire of citizens to increase the quantity of domestic tourist visits, which so far have only focused on Sendang Bulus and Rowo Jombor. Rowo Jombor was officially handed over by Krakit Village in the east of Jimbung Village. However, the access to get to Rowo Jombor has to cross Jimbung Village. The high attractiveness of Rowo Jombor to domestic tourists, made Jimbung village plan to build a tourist and parking area that borders directly with Rowo Jombor. This is expected to fasten the economic wheels in Jimbung Village.

Geoinformation technologies including Remote Sensing and GIS have been developed very well recently [13, 14, 15, 16, $17,18]$. In order to support development plan of certain area and to evaluate existing condition [19], researches have invented spatial model [20], 4D-GIS Model [21], GIS-based multicriteria decision analysis techniques [22], or even better GIS augmented computational intelligence technique [23]. Those approaches are very strong technically. 
However, in certain circumstance, especially in developing countries, incorporating local participation can greatly improve the end product of GIS analysis [9]. This paper shows that using ordinary protocol of Geoinformation Technology that has been described in the methodology, the output map can only describe the existing features within the study area (Figure 3). However, if local participation is incorporated into the protocol, valuable complementary information and its justification appears spontaneously. This can improve the product of geoinformation technology itself [8].

\section{CONCLUSION}

Based on the explanation of these results, the following conclusions can be drawn:

1. Promising sectors in Jimbung Village includes the industrial sector, processed food, animal husbandry and agriculture, as well as tourism.

2. Participatory mapping can improve the geoinformation technology by incorporating justification of the conversion of agricultural land in Jimbung Village and it allows to compile the aspiration of local community about their expectation in the future development.

\section{REFERENCES}

[1] Öceylan E., Erbas M., Tolon M., Kabak M., Durğut T., "Evaluation of freight villages: A GIS-based multicriteria decision analysis," Computers in Industry 76, 38-52 (2016).

[2] Sharma R., Kamble S.S., Gunasekaran A., "Big GIS analytics framework for agriculture supply chains: A literature review identifying the current trends and future perspectives," Computers and Electronics in Agriculture 155, 103-120 (2018).

[3] Nyantakyi-Frimpong H. "Visualizing politics: A feminist political ecology and participatory GIS approach to understanding smallholder farming, climate change vulnerability, and seed bank failures in Northern Ghana," Geoforum 105, 109-121 (2019).

[4] Picuno P., Cillis G., Statuto D., "Investigating the time evolution of a rural landscape: How historical maps may provide environmental information when processed using a GIS," Ecological Engineering 139, 105580 (2019).

[5] En Chee Y., Wilkinson L., Nicholson A.E., Quintana-Ascencio P.F., Fauth J.E., Hall D., Ponzio K.J., Rumpff L., "Modelling spatial and temporal changes with GIS and Spatial and Dynamic Bayesian Networks," Environmental Modelling \& Software 82, 108-120 (2016).

[6] Cano M., Garzón E. Sánchez-Soto P.J., "Historic preservation, GIS, \& rural development: The case of Almería province, Spain. Applied Geography. 42, 34-47 (2013).

[7] Badan Pusat Statistik., [Kecamatan Kalikotes Dalam Angka 2017], Badan Pusat Statistik Kabupaten Klaten. $78 \mathrm{p}(2017)$.

[8] Longley P.A., Goodchild M.F., Maguire D.J., Rhind D.W., [Geographic Information Science and Systems], John Wiley and Sons. Danvers. 460 p (2015).

[9] Tian B., [GIS technology applications in environmental and earth sciences], CRC Press. Boca Raton. $256 \mathrm{p}$ (2017).

[10] Malczewski J., Rinner C., [Multicriteria Desicion Analysis in Geographic Information Science], Springer. New York. 331p (2017).

[11]Bishop W., Grubesic T.H., "Geographic Information: Organization, Access and Use], Springer. Cham. 214p (2017).

[12] Chang K.T., [Introduction to Geographic Information Systems]. McGraw-Hill Education. New York. 444p (2019).

[13] Singh A., "Remote sensing and GIS applications for municipal waste management," Journal of Environmental Management 243, 22-29 (2019). 
[14] Gob F., Gautier E., Virmoux C., Grancher D., Tamisier V., Primanda K.W., Wibowo S.B., Sarrazin C., De Bélizal E., Ville A., Lavigne F., "River responses to the 2010 major eruption of the Merapi volcano, Central Java, Indonesia," Geomorphology 273, 244 - 257 (2016).

[15] Wibowo S.B., Lavigne F., Mourot P., Métaxian J-P., Zeghdoudi M., Virmoux C., Sukatja C.B, Hadmoko D.S., Mutaqin B.W., "Coupling between Video and Seismic Data Analysis for the Study of Lahar Dynamics at Merapi Volcano, Indonesia," Géomorphologie : relief, processus, environnement 21(3): 251-266 (2015).

[16] Ville A., Lavigne F., Virmoux C., Brunstein D., De Bélizal E., Wibowo S. B., Hadmoko D. S., "Geomorphological evolution of the Gendol valley following the October 2010 eruption of Mt Merapi (Java, Indonesia)," Géomorphologie : relief, processus, environnement 21 (3), 235-250 (2015).

[17] Cassel M., Piégay H., Lavé J., Vaudor L., Hadmoko D.S., Wibowo S.B., Lavigne F., "Evaluating a 2D imagebased computerized approach for measuring riverine pebble roundness," Geomorphology 311 : 143-157 (2018).

[18] Samodra G., Hadmoko D.S., Wicaksono G.N., Adi I.P., Yudinugroho M., Wibowo S.B., Suryatmojo H., Purwanto T.H., Widartono B.S., Lavigne F., "The March 25 and 29, 2016 landslide-induced debris flow at Clapar, Banjarnegara, Central Java," Landslides 15 (5) : 985-993 (2018).

[19] Wibowo, S.B., [Utilisation des classifications d'Oldeman et de Schmidt-Ferguson pour l'aptitude culturale des sols à Batu, Indonésie]. In S. Khan, H.G.H Savenije, S. Demuth, P. Hubert (dir.). Hydrocomplexity: new tools for solving wicked water problems. IAHS publication, 338, 181-182 (2010).

[20]Ben Khalfallah C., Saidi S., "Spatiotemporal floodplain mapping and prediction using HEC-RAS - GIS tools: Case of the Mejerda river, Tunisia," Journal of African Earth Sciences 142, 44-51 (2018).

[21] Wang H., Chen D., Duan H., Yin F., Niu Y., "Characterizing urban building metabolism with a 4D-GIS model: A case study in China," Journal of Cleaner Production. 228, 1446-1454 (2019).

[22] Arabameri A., Pradhan B., Rezaeid K., Conoscenti C., "Gully erosion susceptibility mapping using GIS-based multi-criteria decision analysis techniques," Catena 180, 282-297 (2019).

[23] Choudhury S., Parida A., Pant R.M., Chatterjee S., "GIS augmented computational intelligence technique for rural cluster electrification through prioritized site selection of micro-hydro power generation system," Renewable Energy 142, 487-496 (2019). 